\title{
Potential ecological risk assessment and prediction of heavy- metal pollution of soil surrounding the drilling waste deposition site
}

\author{
Justyna Kujawska ${ }^{1, *}$ and Wojciech $\mathrm{Cel}^{1}$ \\ ${ }^{1}$ Lublin University of Technology, Faculty of Environmental Engineering, Nadbystrzycka 40B Street, 20-618 Lublin, Poland
}

\begin{abstract}
Owing to their toxicity, heavy metals constitute a serious threat to the environment. In the pages that follow, we will report the results of evaluation of the potential ecological risk and trend of soil heavy metal pollution surrounding the drilling waste deposition site in western Poland. The concentrations of heavy metals: $\mathrm{Cd}, \mathrm{Cr}, \mathrm{Cu}, \mathrm{Pb}$ were determined by inductively coupled plasma optical emission spectrometry. The procedure used for potential ecological risk assessment was as proposed by Hakanson (1980). The calculated potential ecological risk factors come in the following order $\mathrm{E}_{\mathrm{R}}^{\mathrm{i}}(\mathrm{Cd})>\mathrm{E}_{\mathrm{R}}^{\mathrm{i}}(\mathrm{Pb})>\mathrm{E}_{\mathrm{R}}^{\mathrm{i}}(\mathrm{Cu})>\mathrm{E}_{\mathrm{R}}^{\mathrm{i}}(\mathrm{Cr})$, which shows that $\mathrm{Cd}$ is the most important factor leading to risk. The uniform model was employed to determine the time in which $\mathrm{Cd}$ concentration will exceed the permissible concentration level, as regulated by Polish Law. The Pearson correlation coefficient was employed along with the correspondence analysis in order to determine the relationships between heavy metal concentrations.
\end{abstract}

\section{Introduction}

World energy demand is on the constant increase. Poland's primary energy source is coal, however, with the discovery of shale gas reserves, it has emerged that fracking might provide an alternative energy source not only in Poland, but also in other parts of Europe where these resource has been found [1]. Between 2010-2015, the total of 72 test drilling rigs were installed (as of 04.02.2017) [2]. The growing interest in shale gas production has led to the increase in the amount of produced the drilling waste, which amounts to $80 \%$ of total industrial waste produced in Poland [3].

Despite numerous successful initiatives towards their reduction and recycling, a considerable amount of mine waste is still deposited. By-products of mining are primarily stored in the form of spoil heaps or mine waste dumps. In Poland approximately 123 million tonnes of industrial waste was produced, which in 2016 was stored on the total area of 8374.3 ha of unreclaimed land, such as spoil heaps or mine waste deposition sites [4].

Mine waste is full of chemicals, including heavy metals. Research is being conducted on finding optimal methods for their disposal [5-7]. The most drilling wastes are stored in landfills. Contaminants from the deposited waste migrate to ground water, surface water and soil, which triggers environmental worries and social discontent. It is, nevertheless, the heavy metal contamination that is the source of the biggest fears $[8,9]$.

Weathering, leaching and decomposition of waste products are the major sources of soil contamination. Pollution in the vicinity of spoil heaps constitutes a serious health threat, as the contaminants are easily absorbed by human organisms. Soils retain heavy metals over extended time periods, which is a consequence of the fact that heavy metals do not undergo microbial or chemical decomposition. Nevertheless, what does occur are changes in their chemical form (speciation) or bioavailability. The presence of heavy metals in soil may substantially inhibit biodegradation of organic pollutants. Heavy metal contamination of soil is a serious risk factor for both people and ecosystems [10].

The increase in the volume of the drilling waste produced during shale gas search and mining has led to the growth in the body of literature and research into the effects of mine waste on the environment. A number of researchers have investigated the mineral composition of mine waste [11], chemical speciation of heavy metals in mine waste [12, 13], characteristics of heavy metal pollution in soils contaminated with mine waste $[14,15]$, or effect of mine waste toxicity on plants and living organisms [16-21].

Up to date there have been no studies evaluating potential ecological risk of heavy metal contamination of soils in the vicinity of the drilling waste deposition site. It was resolved that ecological risk assessment based on integrated ecological risk index should provide an optimal solution for the undertaken task. Ecological risk assessment procedures have already been introduced in the USA, Australia, Canada, whereas in Europe (Germany, Great Britain, Sweden, Finland, Spain,

\footnotetext{
* Corresponding author: j.kujawska@pollub.pl
} 
Belgium) the regulations concerning acceptable pollution levels in soils based on eco-receptors were introduced 10 years ago [21]. In Poland the recently amended environmental protection law (2016) accounts for the accepted values of permissible pollution levels in the environment [22].

In the paragraphs to follow we will attempt to conduct an analysis of heavy metal contamination, potential ecological risk assessment and prognosis of heavy metal contamination of soil in the vicinity of mine waste deposition site. The data for the study was obtained from the results of heavy metal content measurements carried out in the area surrounding the drilling waste deposition site. The potential ecological risk was estimated by means of the Potential Ecological Risk Index (PERI) method proposed by Hakanson [23]. In statistical analysis, we have employed the Pearson correlation coefficient to determine the relationships between heavy metal concentrations. Secondly, the correspondence analysis was used to link the obtained relationships between the soil sampling sites and heavy metal content with a purpose of predicting the heavy metal pollution trend in the soil surrounding the drilling waste deposition site. The presented investigation is aimed to provide relevant data in the search for a suitable strategy for the prevention or reduction of heavy metal pollution of soils in the vicinity of the drilling waste deposition site.

\section{Material and Methods}

Examinations were carried out at a mine facility established during shale gas search in eastern Poland. At the facility, the drilling waste (drilling fluids and drill cuttings) are mixed with coagulant-aluminium sulphate (VI) (up to a few percent), dewatered in chamber filter press, mixed with cement (up to $10 \%$ ) and in such a form deposited in the open mining pit. Soil was sampled at 14 points surrounding the landfill (Fig. 1).

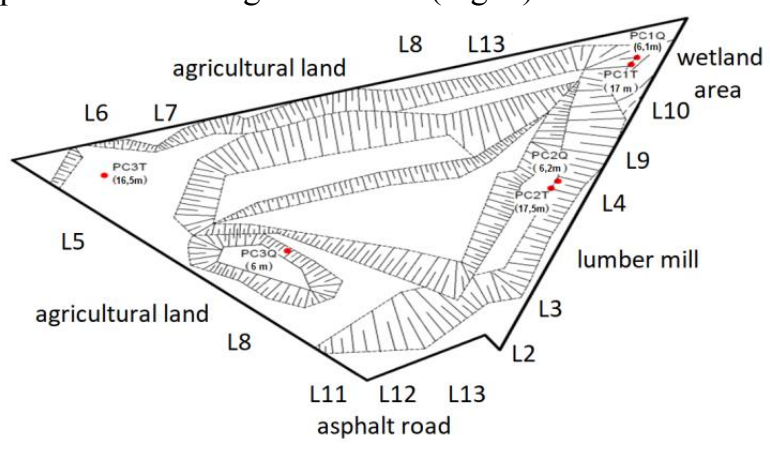

Fig. 1. The object of the study: a real drilling waste deposition site.

The prepared soil and coal gangue samples were passed through a $0.075 \mathrm{~mm}$ sieve for the heavy-metal measurement procedure. The content of heavy metals, $\mathrm{Cd}, \mathrm{Cr}, \mathrm{Cu}, \mathrm{Pb}$, was determined by means of ICP-OES Ultrace 238 sequential spectrometer (Jobin YvonHorriba France) using direct calibration method after microwave digestion (Multiwave 3000, Anton Paar). The samples of homogenized soil $(1 \mathrm{~g})$ were digested in acid mixture of $\mathrm{HNO}_{3}: \mathrm{HCl}(5: 2)$ and water samples $(15 \mathrm{~g})$ were digested in $\mathrm{HNO}_{3}(3 \mathrm{~mL})$. The digestion process lasted $45 \mathrm{~min}$ at $180^{\circ} \mathrm{C}$ and was performed at the pressure of 18 bars. Metal concentrations were determined at different wavelengths (213-395 nm). Detection limits for particular metals did not exceed 10 ppb.

This research also employed the Potential Ecological Risk Index (PERI) proposed by Hakanson (1980) to evaluate the potential ecological risk of heavy metal pollution. PERI is formed by three basic modules: degree of contamination $\left(C_{D}\right)$, toxic-response factor $\left(T_{R}\right)$ and potential ecological risk factor $\left(\mathrm{E}_{\mathrm{R}}\right)$. According to this method, the potential ecological risk index of a single element $\left(\mathrm{E}_{\mathrm{i}}^{\mathrm{R}}\right)$ and a comprehensive potential ecological risk index (RI) can be calculated via the following equations:

$$
\begin{gathered}
c_{f}^{i}=c_{D}{ }^{i} / c_{R}{ }^{i} \\
E_{R}^{i}=T_{\mathrm{R}}{ }^{\mathrm{i}} \cdot c_{f}^{i} \\
R I=\sum_{i-1}^{m} E_{R}^{i}
\end{gathered}
$$

where $c_{D}{ }^{i}$ is the measured concentration of heavy metals at each sampling point; $c_{R}{ }^{i}$ is the reference value, here the background value of each heavy metal in soil is used; $c_{f}^{i}=c_{D}{ }^{i} / c_{R}{ }^{i}$ is the pollution of a single element factor; $E_{R}^{i}$ is the potential ecological risk index of a single element; RI is a comprehensive potential ecological risk index; and $T_{\mathrm{R}}{ }^{\mathrm{i}}$ is the biological toxic factor of a single element, which is determined for $\mathrm{Zn}=1, \mathrm{Cr}=2, \mathrm{Cu}=\mathrm{Pb}=5$ and $\mathrm{Cd}=30$ [23].

The statistical analysis of the results from the study included the correspondence and the correlation methods, and was carried out with the STATISTICA software copy purchased by Lublin University of Technology.

\section{Results and Discussion}

Table 1 shows heavy metal concentrations in the soils near the drilling waste deposition site. The obtained concentrations were compared with the acceptable concentration limits of heavy metals in agricultural soils, according to the regulation of the Polish Minister of Environment regarding soil sampling in the context of land surface pollution assessment, published in the Journal of Laws [24]. The heavy metal content determined in the soil samples does not exceed the acceptable limits specified by the relevant law. The obtained results have been furthermore compared with the average heavy metal concentration levels in Poland, i.e. $10 \mathrm{mg} \mathrm{kg}^{-1}$ for $\mathrm{Cr}$, and $0.59 \mathrm{mg} \mathrm{kg}-1$ for $\mathrm{Cd}$. Concentrations of copper and lead in the majority of tested samples slightly exceeded the average values for typical soils in Poland [25].

\subsection{Pearson correlation analysis}

Pearson correlation analysis was employed in the study with the purpose of assessing the source of heavy metals. Table 2 collates the established correlation coefficients for particular heavy metals.

A positive correlation between heavy metal concentrations in samples would suggest their interdependence, similar behaviour and common source. 
A negative correlation indicates the lack of common features between metals. Our study shows a positive correlation at the level of 0.1 between the concentration of $\mathrm{Cd}$ and $\mathrm{Cu}$, a positive correlation at the level of 0.2 between $\mathrm{Cd}$ and $\mathrm{Pb}$, and a positive correlation at the level of 0.5 between $\mathrm{Cu}$ and $\mathrm{Pb}$.

Table 1. Concentrations of heavy metals in soil in the vicinity of the drilling waste deposition site.

\begin{tabular}{|c|c|c|c|c|c|c|c|c|c|c|c|c|c|c|c|c|c|c|}
\hline C & L1 & L2 & L3 & L4 & L5 & L6 & L7 & L8 & L9 & L10 & L11 & L12 & L13 & L14 & BV & $\begin{array}{c}\text { Low } \\
\text { limits }\end{array}$ & $\begin{array}{c}\text { Mean } \\
\text { C }\end{array}$ \\
\hline \multicolumn{10}{|c|}{} \\
\hline $\mathrm{Cd}$ & 1.40 & 1.37 & 1.57 & 1.76 & 1.54 & 1.54 & 1.33 & 1.53 & 1.44 & 1.39 & 1.20 & 1.39 & 1.18 & 1.18 & 0.6 & 5 & 0.59 \\
\hline $\mathrm{Cr}$ & 19.48 & 19.57 & 19.65 & 20.11 & 20.69 & 19.31 & 19.71 & 24.42 & 21.19 & 22.23 & 19.09 & 23.34 & 22.60 & 22.51 & 71.22 & 500 & 10 \\
\hline $\mathrm{Cu}$ & 13.68 & 13.05 & 14.11 & 11.76 & 17.87 & 15.11 & 14.12 & 13.44 & 10.98 & 9.77 & 13.91 & 14.90 & 12.84 & 12.23 & 20.39 & 300 & 11 \\
\hline $\mathrm{Pb}$ & 16.24 & 16.66 & 18.28 & 18.06 & 18.32 & 16.31 & 18.28 & 14.73 & 15.25 & 12.17 & 15.70 & 16.98 & 13.28 & 18.44 & 19.35 & 500 & 22.5 \\
\hline
\end{tabular}

$\mathrm{BV}$ - background values

Low limits - acceptable concentration limits for substances in land type II**: arable land, family allotment gardens, orchards, permanent meadows, permanent pastures, lands under ponds, lands under ditches, specified in the in the Journal of Laws regarding soil sampling in the context of land surface pollution assessment [24].

Mean C - mean heavy metal concentration in Polish soils specified in: Monitoring of soil chemistry in Poland [25].

Table 2. Results of Pearson correlation analysis between different measured concentrations of heavy metals.

\begin{tabular}{|c|c|c|c|c|}
\hline $\mathrm{R}$ & $\mathrm{Cd}$ & $\mathrm{Cr}$ & $\mathrm{Cu}$ & $\mathrm{Pb}$ \\
\hline $\mathrm{Cd}$ & 1 & -0.160 & 0.132 & 0.281 \\
\hline $\mathrm{Cr}$ & -0.160 & 1 & -0.215 & -0.393 \\
\hline $\mathrm{Cu}$ & 0.132 & -0.219 & 1 & 0.52 \\
\hline $\mathrm{Pb}$ & 0.281 & -0.393 & 0.522 & 1 \\
\hline
\end{tabular}

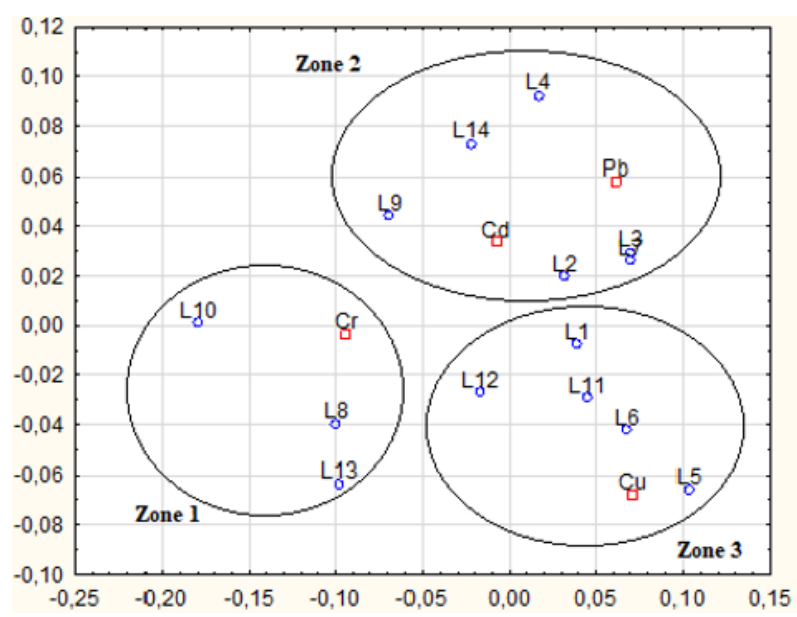

Fig. 2. Correspondence map of relationships between heavy metals and sampling points.

\subsection{Correspondence analysis}

The correspondence analysis was employed with the purpose of determining the major polluting factor in the given area. The analysis accounted for the disparity in heavy metal content levels and different location of soil sampling.

Correspondence analysis provides information regarding the structure of relationships between variables. It is an uncomplicated and intuitive method of establishing relationships between variables [26].
Fig. 2 shows a correspondence map of heavy metal content sampling results. The obtained points have allowed us to determine 3 zones. Zone I: L2. L3. L4. L14. L9; zone II: L1. L12. L11. L6. L5; zone III L10. L13. L8.

$\mathrm{Cr}$ has been detected in the vicinity of zone 3, located in the marshland area, and its concentration is lower than the natural concentration (background levels).

$\mathrm{Pb}$ and $\mathrm{Cd}$ have been found near zone 1, located in the vicinity of the sawmill. The concentrations of these metals may be related to the debris produced in the sawmill, and not exclusively with the drilling waste deposition site.

$\mathrm{Cu}$ has been discovered in zone 2, located along the access roads, and may therefore be explained by the road-related pollution.

\subsection{Potential risk assessment of heavy metal}

The environmental risks of the heavy metals in sediments assessed by the potential ecological risk factor are gathered in Table 3 . The obtained results have been compared with the adjusted grading standard of potential ecological risk of heavy metals in soil, shown in Table 4.

The potential ecological risk indices for $\mathrm{Cr}, \mathrm{Cu}, \mathrm{Pb}$ are low and do not exceed 10. However, the potential ecological risk indices for $\mathrm{Cd}$, whose value exceeds 50, constitute a heavy metal pollution indication.

The ecological risk indices for $\mathrm{Cr}$ are low, so is the risk level. The ecological risk indices for $\mathrm{Cu}$ and $\mathrm{Pb}$ indicate average risk. However, it is $\mathrm{Cd}$ that constitutes the highest risk. The ecological risk indices for $\mathrm{Cd}$ are very strong. The indices for metals come as follows: $\mathrm{E}_{\mathrm{R}}^{\mathrm{i}}(\mathrm{Cd})>\mathrm{E}_{\mathrm{R}}^{\mathrm{i}}(\mathrm{Pb})>\mathrm{E}_{\mathrm{R}}^{\mathrm{i}}(\mathrm{Cu})>\mathrm{E}_{\mathrm{R}}^{\mathrm{i}}(\mathrm{Cr})$

Although the ecological risk indices for $\mathrm{Pb}, \mathrm{Cu}$ and $\mathrm{Cr}$ are low, their impact on the environment cannot be univocally deemed as insignificant. Stuckman's study on the mobility of metals from drill cuttings has shown that these metals exhibit affinity with the oxidising phase and 
a tendency for long-term release of waste products [27, 28].

\subsection{Predicted results}

Our study has shown that the element constituting the most serious environmental risk in soils located around the drilling waste deposition site is $\mathrm{Cd}$. Due to the high values of the ecological risk indices for $\mathrm{Cd}$, its predicted accumulation time around the drilling waste deposition site was calculated using the uniform model.

Table 3. Statistical potential ecological risk index of a single element $\left(\mathrm{E}_{\mathrm{R}}^{\mathrm{i}}\right)$ and comprehensive potential ecological risk index (RI).

\begin{tabular}{|c|c|c|c|c|}
\hline \multicolumn{5}{|c|}{$\mathrm{E}_{\mathrm{R}}^{\mathrm{i}}$} \\
\hline $\mathrm{R}$ & $\mathrm{Cd}$ & $\mathrm{Cr}$ & $\mathrm{Cu}$ & $\mathrm{Pb}$ \\
\hline Maximum & 87.98 & 0.69 & 4.38 & 4.77 \\
\hline Minimum & 58.94 & 0.54 & 2.39 & 3.14 \\
\hline Mean & 70.81 & 0.59 & 3.29 & 4.22 \\
\hline \multicolumn{5}{|c|}{$\mathrm{RI}$} \\
\hline Mean & 991.35 & 8.25 & 46.04 & 59.10 \\
\hline
\end{tabular}

Table 4. The adjusted grading standard of potential ecological risk of heavy metals in soils.

\begin{tabular}{|c|c|c|c|c|}
\hline $\mathrm{E}_{\mathrm{R}}^{\mathrm{i}}$ & $\begin{array}{c}\text { Pollution } \\
\text { degree }\end{array}$ & $\mathrm{RI}$ & $\begin{array}{c}\text { Risk } \\
\text { level }\end{array}$ & $\begin{array}{c}\text { Risk } \\
\text { degree }\end{array}$ \\
\hline $\mathrm{E}_{\mathrm{R}}^{\mathrm{i}}<30$ & Slight & $\mathrm{RI}<40$ & $\mathrm{~A}$ & Slight \\
\hline $30 \leq \mathrm{E}_{\mathrm{R}}^{\mathrm{i}}<60$ & Medium & $40 \leq \mathrm{RI}<80$ & $\mathrm{~B}$ & Medium \\
\hline $60 \leq \mathrm{E}_{\mathrm{R}}^{\mathrm{i}}<120$ & Strong & $80 \leq \mathrm{RI}<160$ & $\mathrm{C}$ & Strong \\
\hline $120 \leq \mathrm{E}_{\mathrm{R}}^{\mathrm{i}}<$ & $\begin{array}{c}\text { Very } \\
240\end{array}$ & $\mathrm{RI} \geq 320$ & $\mathrm{D}$ & $\begin{array}{c}\text { Very } \\
\text { strong }\end{array}$ \\
\hline $\mathrm{E}_{\mathrm{R}}^{\mathrm{i}} \geq 240$ & $\begin{array}{c}\text { Extremely } \\
\text { strong }\end{array}$ & - & - & - \\
\hline
\end{tabular}

The uniform model was obtained from the formula:

$$
\begin{aligned}
& t=Q / V_{0} \\
& Q=a-b \\
& A=2 Q / T
\end{aligned}
$$

where $\mathrm{a}$ is heavy-metal concentration in soil sample; $\mathrm{b}=$ $0.6 \mathrm{mg} \mathrm{kg}^{-1}$ is the background value of heavy metal in soil, (acceptable concentration limits for $\mathrm{Cd}$ in land type II: arable land, family allotment gardens, orchards, permanent meadows, permanent pastures, lands under ponds, lands under ditches, specified in the in the Journal of Laws $A$ is cumulative acceleration rate; $V_{0}$ is cumulative rate (for year of 2016); and $\mathrm{T}=10$ (the total heavy-metal accumulation years since the facility of mining waste was put into production) [29].

According to the uniform model, after 5 years $\mathrm{Cd}$ concentration should exceed the acceptable concentration limits specified in the in the Journal of Laws regarding soil sampling in the context of land surface pollution assessment [24].

\section{Conclusion}

Potential ecological risk assessment of soils in the vicinity of mine waste deposition sites provides a useful tool for the minimisation of the impact of these areas on the environment.

Our study has proven that the soil in question exhibits slight pollution by $\mathrm{Cr}, \mathrm{Cu}$ and $\mathrm{Pb}$ and medium pollution by $\mathrm{Cd}$. Pearson correlation analysis results indicate that while positive correlation is observed with regards to relationships between $\mathrm{Cu}, \mathrm{Pb}$ and $\mathrm{Cd}-\mathrm{Cr}$ is negatively correlated with all the investigated metals. Based on the correlation analysis, we may infer that the concentrations of $\mathrm{Cd}, \mathrm{Cu}$ and $\mathrm{Pb}$ are to a large extent of the common source, which may in fact be the mine waste treatment site. On the other hand, $\mathrm{Cr}$ concentration appears to be of a different origin.

Correspondence analysis has allowed us to divide the metals into 3 zones. While the zones have been shown to exhibit dependence on the facilities of the mine complex, correspondence analysis has failed to show explicitly the impact of heavy metals from the landfill.

The results of potential ecological risk assessment indicated that the potential ecological risk was arranged in the order of $\mathrm{E}_{\mathrm{R}}^{\mathrm{i}}(\mathrm{Cd})>\mathrm{E}_{\mathrm{R}}^{\mathrm{i}}(\mathrm{Pb})>\mathrm{E}_{\mathrm{R}}^{\mathrm{i}}(\mathrm{Cu})>\mathrm{E}_{\mathrm{R}}^{\mathrm{i}}(\mathrm{Cr})$. Cadmium was the key influence factor to cause the risk, and its mean value of $\mathrm{E}_{\mathrm{R}}^{\mathrm{i}}(\mathrm{Cd})$ amounted to 70.81 .

The predicted results indicate that $\mathrm{Cd}$ will be accumulated in soil. According to the uniform model, the concentration of $\mathrm{Cd}$ in the vicinity of the drilling waste treatment site shall exceed the acceptable concentration level specified in the relevant legal acts in 5 years.

The results obtained from the study offer an effective way of estimating the time during which a given facility may become a threat to the environment. Potential ecological risk assessment methods could help in determining the time upon which a given facility, such as the object of the presented study, should be closed.

\section{References}

1. A. Hoffman, G. Olsson, A. Lindström, Shale Gas and Hydraulic Fracturing: Framing the Water Issue (Report Nr 34, SIWI, Stockholm 2014)

2. Www.pgi.gov.pl, date 10.08.2018.

3. S. Wasilewski, P. Skotniczny, Mining waste dumps -modern monitoring of thermal and gas activities, Gospod Surowcami Min. 31, 1 (2015)

4. $\quad$ stat gov.pl, date 10.08.2018. 
5. R. Babko, K. Jaromin-Gleń, G. Łagód, M. Pawłowska, A. Pawłowski, Desalin Water Treat. 2016, 3, 57 (2016)

6. R. Babko, T. Kuzmina, G. Łagód, K. Jaromin-Gleń, Y. Danko, M. Pawłowska, A. Pawłowski, J Environ Qual. 1, 46 (2017)

7. R. Babko, K. Jaromin-Gleń, G. Łagód, Y. Danko Y., T. Kuzmina, M. Pawłowska, A. Pawłowski, J Environ Qual. 4, 46 (2017)

8. A. ÖzarsIan, P.N. Martens, T. Olbrich, M. Röhrlich, 17th International Mining Congress and Exhibition of Turkey- IMCET2001 (2001)

9. S. Dumała, M. Dudzińska Rocz. Ochr. Sr. 17 (2015)

10. A. Raymond, A. Wuana, F. E. Okieimen, Heavy Metals in Contaminated Soils: A Review of Sources, Chemistry, Risks and Best Available Strategies for Remediation, Int Sch Res Notices 1 (2011)

11. J. Fijał, A. Gonet, A. Jamrozik, AGH Drilling, Oil, Gas 32, 3 (2015)

12. M. Stuckman, C.L. Lopano, J.A. Hakal, 18th International Conference on Heavy Metals in the Environment (Ghent, Belgium, 2016)

13. K. Piszcz, J. Luczak, J. Hupka, Mobility of shale drill cuttings constituents, Physicochem Probl Mi 50, 2 (2014)

14. A. Gonet, Elaboration of a method of organicmineral the drilling waste processing in the aspect of its management (Wydział Wiertnictwa Nafty i Gazu, Kraków, Poland, 2006)

15. Technical Report 2011 - 35. Land farming of the drilling wastes. Impacts on soil biota within sandy soils in Taranaki (Year 1 of 3) (Taranaki Regional Council. Document: 894052, ISSN: 0114 - 8184)

16. D.F Ogeleka, L.E Tadararo-Aherobo, BEPLS, 2 (2013)
17. A.A. Enuneku, S. U. Ayobahan, SU, J. Appl. Sci. Environ. Manage 18, 4 (2014)

18. A. Soegianto, B. Irawan, M. Affand, GJER 2, 1 (2008)

19. L.F. Viega, Z.T. Tostes, M.V. Reynier, G.F.R. Brandao, F.F. Oliveira, Setac 22nd Annual Meeting. Changing Environmental Awareness: Societal Concerns and Scientific Responses (Baltimore, Maryland, USA, 2001)

20. R.F. Nunez, A. Chiappa, M. Vasquez-Botello, C. De la Rosa-Duque, C. Vanegas, Setac 22nd Annual Meeting. Changing Environmental Awareness: Societal Concerns and Scientific Responses (Baltimore, Maryland, USA, 2001).

21. G. Łagód, M. Chomczyńska, A. Montusiewicz, J. Malicki, D. Stransky, Ecol Chem Eng S. 4, 21 (2014)

22. A. Karczewska, C. Kabała, Soil Sci. Ann. 68, 2 (2017)

23. L. Hakanson, Water Res. 14 (1980)

24. Regulation of the Polish Minister of Environment of 1 September 2016

25. Monitoring of soil chemistry in Poland 2015-2017. Report 2017 IUNG Institute of Soil Science and Plant Cultivation - IUNG PIB

26. A. Staniszyn, Easy course of statistics. Volume 3. Multidimensional analysis (Wydawnictwo StatSoft Poand Sp.z.o.o. Krakow, 2007)

27. S. Westerlund, S.J. Cripps, Minimizing the environmental effects of drilling operations (Aberdeen, IBC Global Conferences Limited, 2000).

28. M. Stuckman, C.L. Lopano, J. A. Hakal, 18th International Conference on Heavy Metals in the Environment (Ghent, Belgium 2016)

29. X. Jiang, W. X. Lu, H. Q. Zhao, Q. C. Yang, Z. P. Nat, Hazards Earth Syst. Sci. 14 (2014). 